\title{
Solar energy in urban community in City of Salzburg, Austria
}

\author{
Helmut Strasser ${ }^{1, *}$, Boris Mahler ${ }^{2}$, Norbert Dorfinger ${ }^{3}$ \\ ${ }^{1}$ SIR Salzburger Institut für Raumordnung und Wohnen, Salzburg, Austria \\ ${ }^{2}$ Steinbeis Transferzentrum, Energie-, Gebäude- und Solartechnik, Stuttgart, Germany \\ ${ }^{3}$ Salzburg AG, Salzburg, Austria \\ * Corresponding author. Tel: +43 662 623455, Fax: +43 662 629915, E-mail: helmut.strasser@salzburg.gv.at
}

\begin{abstract}
Lehen is the largest district of City of Salzburg, close to the city centre and with high quality of infrastructure of public transport. Since the last decades the district was confronted with essential changes. The use of the area of the former utility means a huge potential for further development of the district. High share of renewable energy should be the main focus of the project, considering existing heat supply with district heating. High standards of buildings and large-scale solar system are the main elements of the energy concept. The use of a heat pump ensures an efficient increase of solar gains and leads to low primary energy demand resp. $\mathrm{CO}_{2}$ emissions. The new building area was also seen as a chance for modernization activities in existing building stock around. Energy efficient pumps and lightning as well as PV modules in the facades will ensure high share of renewable energy also for electricity demand. First results show the way for further projects - concerning effective steering of complex processes and technologies to achieve total $\mathrm{CO}_{2}$-reductions in urban areas.
\end{abstract}

Keywords: General development plan, Urban communities, Process of energy planning, Solar optimization

\section{Introduction}

The district of Salzburg-Lehen is situated quite close to the city centre of Salzburg. The appearance of Lehen was for long years dominated by residential buildings from 1950 to 1970, high amount of school buildings, the main soccer stadium of Salzburg, the head-quarter of the utility and a main traffic road. Obviously caused by the living situation in mostly not renovated buildings and the traffic situation the district was endangered to get more and more social problems. Considering the very attractive location the potential for establishing a new and attractive district in Salzburg was seen. With the opening of a new train station Lehen is now connected to the new city train which means another improvement of living quality of the district. The movement of the utility and the football stadium to other sites mean new chances for further development. Meanwhile the main city library was established on the site of the former soccer stadium.

On the site of the former utility a new residential and commercial area was initiated. In a competition a master plan of the launched project "Stadtwerk Lehen" was developed. Residential buildings with apartments and commercial areas, a kindergarten, a student's hostel and a "Competence park" with four live science buildings, a hotel and the renovation of the former office building are foreseen. Besides that, there is an existing building stock around the areas of the utility with residential buildings from 1950 - 1960, most of them without any thermal renovation and equipped with individual heating system with oil or gas. So the newbuilt area was seen as a chance also for the surrounding retrofit areas. Energy efficiency of the buildings and the integration in the energy supply concept of the new buildings of "Stadtwerk Lehen" became a concrete perspective for city planners. This causes an over-all renovation as a requirement for the further project development. 
Table 1. Key figures

\begin{tabular}{ll}
\hline Total area & $155.000 \mathrm{~m}^{2}$ \\
Owners & $\begin{array}{l}\text { Social and commercial housing associations, } \\
\text { city of Salzburg }\end{array}$ \\
\hline Existing buildings & $50.000 \mathrm{~m}^{2}$ \\
\hline Number of dwelling & 623 \\
Average age of existing buildings & $60-70$ years \\
Type of buildings & $85 \%$ residential, 15\% commercial \\
\hline New buildings & $105.000 \mathrm{~m}^{2}$ \\
\hline Number of dwellings & 550 \\
Type of buildings & $80 \%$ residential, 20\% commercial \\
\hline
\end{tabular}

Table 1 shows the key-figures of the area. Besides the goals of urban development and motivated by the discussion of a new communal development plan which fulfils criteria of sustainability the project of "Stadtwerk Lehen" was created as a pilot project for sustainable urban development. Main performance criteria concerning energy were defined as:

- Low energy standard for buildings

- Energy efficient pumps and lightning of public areas

- High rate of renewable energy for energy supply

In addition to that energy supply system and integration of renewable energy should also be optimized related to existing district heating system, since district heating is based on high shares of available industrial waste heat resources. Thus the main focus of project development was the optimization of the energy supply concept. As there are different approaches for new buildings and renovation, a couple of involved partners and clear targets defined by funding programs the definition of an optimized methodology for the realization process became an important issue. Project realization is scheduled for 2005 - 2013, Table 2 shows the concrete time-table.

Table 2. Time Table

\begin{tabular}{ll}
\hline Preparation phase & $2005-2007$ \\
\hline Planning phase & $2007-2010$ \\
\hline Construction phase & $2009-2011$ (for housing, commercial buildings will be finished later) \\
\hline Completion & 2013 (for housing, commercial buildings, renovation will be ongoing) \\
\hline
\end{tabular}

\section{Methodology}

Successful realization of the project has to be built on two main focuses. On the one hand the steering of the realization process with involvement of many institutions and stakeholders is essential for project success. On the other hand the optimization of technologies on energy efficiency and renewable energy is crucial for achieving performance criteria.

\subsection{Realization process}

Effective steering of the realization process needs first identification of the relevant players and their roles. Furthermore binding instruments for realization and effective monitoring of the process itself are essential.

Partners and their roles: Besides the City of Salzburg several social housing associations / project developers and the former utility that is/was owner of the area involved. This needs 
clear identification of their roles in the project, because partly the partners have different roles in the project.

Quality agreement: A quality agreement was worked out and signed by all partners. This agreement includes a commitment to the performance criteria, minimum requirements of building standards and the obligatory fulfillment of the energy supply concept.

Steering group / Working groups: A monthly steering group of leaders of key actors was installed to monitor fulfillment of quality agreement. The steering group is chaired by the city of Salzburg. In addition to the steering group working groups were established.

Fig. 1 shows the different involvement of partners depending on their specific roles.

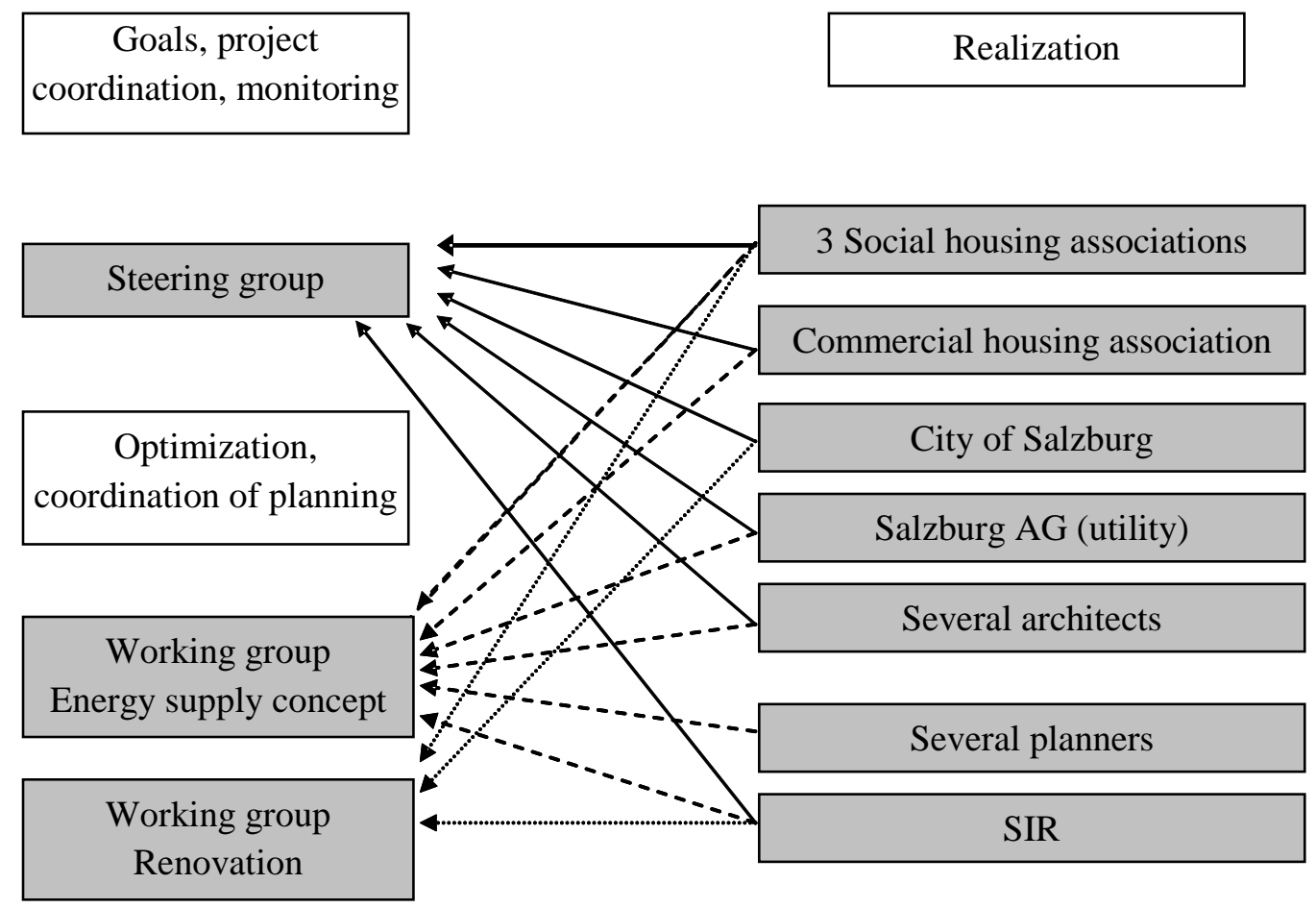

Fig. 1. Process organization

\subsection{Building standards}

Focus of Stadtwerk Lehen was put on high share of renewable energy, both for heat and electricity demand. Ambitious energy performance of the buildings was seen as the basis for achieving the targets. On the other hand there are existing rules of funding schemes which are limiting the investment costs for social housing. Thus low-energy standard was required as minimum instead of more ambitious passive house standard. Table 3 shows the targets for new buildings and renovation. Based on this target minimum U-values for new buildings and retrofit were defined.

Table 3. Minimum requirements of building standards

\begin{tabular}{lc}
\hline & $\begin{array}{c}\text { Specific heat demand } \\
\left(\mathrm{kWh} / \mathrm{m}^{2} . \mathrm{a}\right)\end{array}$ \\
\hline New buildings & $<20$ \\
Renovation & $<30$ \\
\hline
\end{tabular}


For new buildings required standards were contracted with involved housing associations and included in the calls-for-tender. For existing buildings project had to start with increasing motivation for renovation since there was no instant need for overall renovation within the tenants. Thus a detailed study on chances of modernization was done in one part of the existing area called "Strubergassensiedlung". This study was explicitly performed by an external expert, who has also no fear on possible conflicts and who has no expectation of further planning jobs. Goal of this study was to show the chances of renovation - concerning improvements in energy consumption but also related to issues of quality of life (quality of apartments, quality of public space ...) and economic benefits. Based on detailed analyses of the buildings and concerned to energy standards several variants were analysed:

- Standard-renovation

- Factor 10- renovation

- Passive-house-standard-renovation resp. for addition of another storeys

Table 4 shows needed standards of main components of renovation.

Table 4. Thermal standards of main components of renovation

\begin{tabular}{|c|c|c|c|c|c|c|c|}
\hline \multirow{3}{*}{$\begin{array}{c}\text { Building } \\
\text { Component }\end{array}$} & \multirow{2}{*}{$\begin{array}{c}\text { Stock } \\
\text { U-value }\end{array}$} & \multicolumn{2}{|c|}{$\begin{array}{l}\text { Variant } 1 \\
\text { Standard }\end{array}$} & \multicolumn{2}{|c|}{$\begin{array}{l}\text { Variant } 2 \\
\text { Factor } 10 \\
\end{array}$} & \multicolumn{2}{|c|}{$\begin{array}{c}\text { Variant } 3 \\
\text { Passive-house }\end{array}$} \\
\hline & & Insulation & U-value & Insulation & U-value & Insulation & U-value \\
\hline & $\mathrm{W} /\left(\mathrm{m}^{2} \mathrm{~K}\right)$ & $\mathrm{cm}$ & $\mathrm{W} /\left(\mathrm{m}^{2} \mathrm{~K}\right)$ & $\mathrm{cm}$ & $\mathrm{W} /\left(\mathrm{m}^{2} \mathrm{~K}\right)$ & $\mathrm{cm}$ & $\mathrm{W} /\left(\mathrm{m}^{2} \mathrm{~K}\right)$ \\
\hline Outer wall & 1,015 & 16 & 0,180 & 20 & 0,138 & 25 & 0,114 \\
\hline Basement ceiling & 1,111 & 12 & 0,231 & 20 & 0,151 & 25 & 0,124 \\
\hline Ceiling above upper floor & 0,812 & 20 & 0,143 & 25 & 0,119 & 30 & 0,101 \\
\hline Pitch of the roof & 1,127 & 27 & 0,154 & 30 & 0,131 & 35 & 0,113 \\
\hline TH-wall to cellar & 1,722 & 16 & 0,194 & 20 & 0,146 & 25 & 0,119 \\
\hline TH-wall to attic & 1,722 & 16 & 0,194 & 20 & 0,146 & 25 & 0,119 \\
\hline Outside door & 2,800 & & 1,250 & & 1,250 & & 0,800 \\
\hline Interior door to unheated & 2,800 & & 1,250 & & 1,250 & & 0,800 \\
\hline Window & & & 0,9 & & 0,85 & & 0,8 \\
\hline Outer wall to soil & 1,596 & 16 & 0,192 & 20 & 0,158 & 25 & 0,129 \\
\hline
\end{tabular}

Considering the different standard of each building of the "Strubergassensiedlung" and individual approaches concerned to actual standards a renovation plan for the whole area was elaborated. For buildings where criteria like quality of apartments are already high standard renovation is suggested. Other buildings where there will be total renovation necessary are suggested to be in passive house-standard.

\subsection{Energy supply concept}

The challenge to integrate renewable energy in existing supply system of the city was solved by following a strategy based on solar energy and district heating system. But there are additional improvements necessary to meet the goal of high share of renewable energy. Increase of solar fraction is achieved by installation of a heat pump in order to increase efficiency of solar collector fields. In addition to that also an own micro-net for heat supply of the whole area is foreseen. This micro-net in combination with planning directives for all of the housing projects allows low temperatures and thus higher solar gains. Fig. 2 shows the hydraulic scheme including the main components solar collector, storage tank, heat pump and micro-net. 


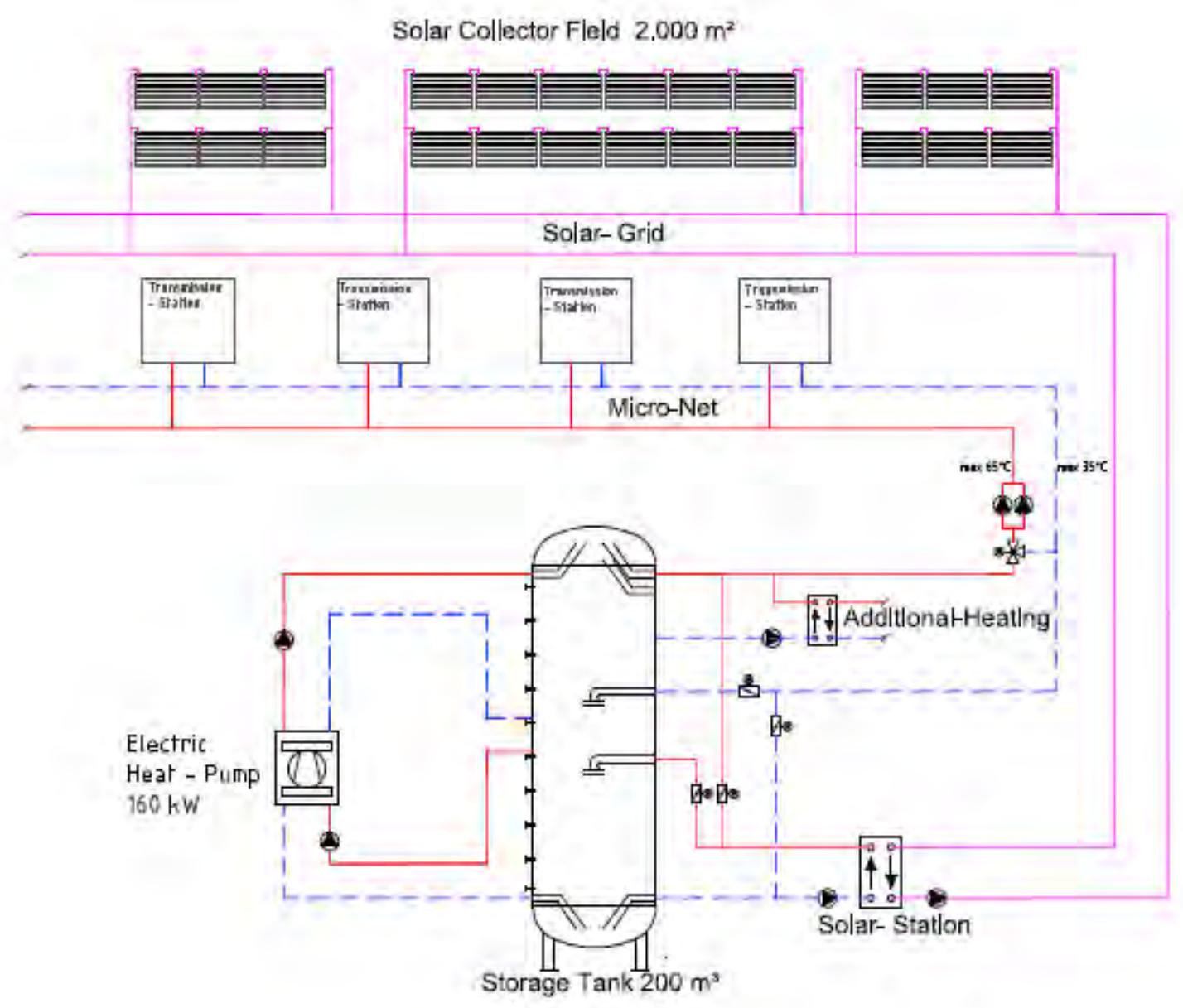

Fig. 2. Hydraulic scheme

Based on the heat-supply concept detailed simulation were done in order to optimize the whole system. Different scenarios were calculated:

- Assumptions of heat-demand because of different time-tables of planning (new residential buildings

- New commercial buildings, existing residential buildings

- Size of collector field

- Size of storage tank

- Size of heat-pump

- Return temperature of micro-net

- Type of heat pump (electricity, gas)

As an example Fig. 3 shows the influence of the return temperature of the micro-net on the collector yield. It is evident, that return temperature has generally a high influence on efficiency of the district heating system (high temperatures mean lower efficiency of solar system and lower capacity of storage tank). By using a heat pump the influence of return temperature on solar yield can be reduced. Simulation shows that there is a higher solar yield in case of $50^{\circ} \mathrm{C}$ return temperature and heat pump in comparison to solution with $30^{\circ} \mathrm{C}$ return temperature without heat pump. 


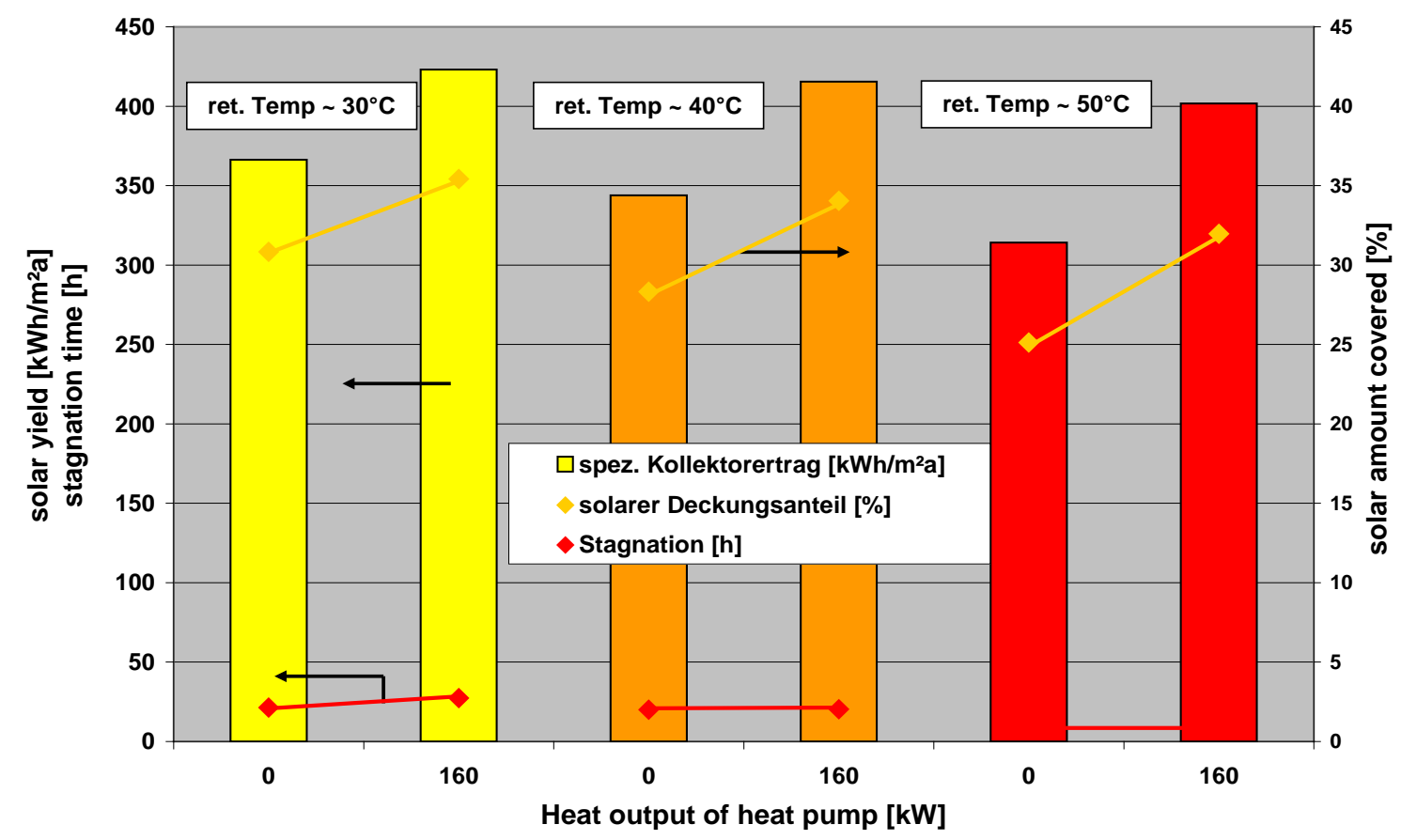

Fig. 3. Influence of return temperature

\section{Results}

Yet new buildings are under construction, required building standards will be achieved. Optimized energy supply concept is based on $2.000 \mathrm{~m}^{2}$ solar collector fields and $2.000 \mathrm{~m}^{2}$ of storage tank in combination with a heat pump and an own low-temperature-micro-net for heat distribution. The calculation of primary energy demand for several variation of energy concept (Fig. 4) showed, that system with solar collectors in combination with electric heat pump leads to the maximum reduction of non-renewable primary energy demand, compared to energy supply based on district heating and solar energy. But it is essential, that the result depends very much on the primary energy figures of the electricity. 


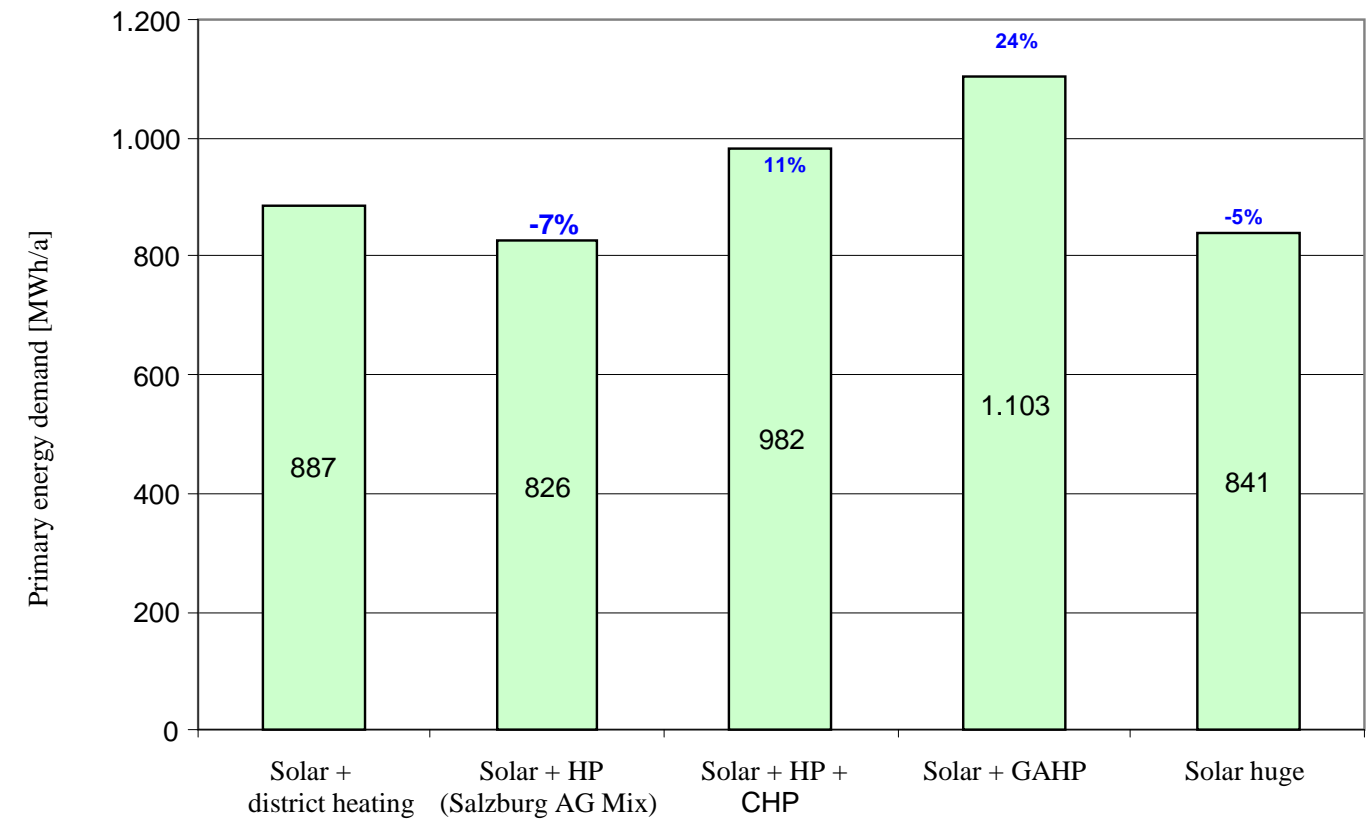

Fig. 4. Primary energy figures

At least, a reduced electricity demand for public areas will be achieved with efficient lightning systems and pumps. Demand will be covered with PV-modules on the several buildings.

\section{Discussion and Conclusion}

Driving forces

For project of "Stadtwerk Lehen" funding programs were the main driving forces at the beginning. Without this opportunity there would be no discussion on development of an ambitious project like it is now neither a development of an energy concept for new building areas and existing community. So for further projects driving forces have to be identified.

\section{Clear roles}

In addition to that funding-programs have led to a signed partnership of relevant institutions and persons. Furthermore roles of partners are defined; in particular there is the defined mission for developing an overall energy concept for the whole area and with defined interfaces to the several planners of the buildings.

Thus further projects which have do be developed need to have clarified before

- who will define the overall energy concept,

- purchased by whom,

- financed by whom,

- at which time of project development?

These questions can become an important issue for development departments of local administrations, although they may not understand as being responsible for energy planning.

Process design for successful renovation projects

Decision making for renovation of existing building stocks is a complex process if there are a couple of stakeholders with each with his own interest addressed. The implementation of a detailed showcase-study was very helpful to show the possibilities of total renovation and its 
options for the overall refurbishment of the district. Thus renovation does not only include insulation of buildings. In fact modernization means more than renovation and offers more possibilities to address the expectations of the tenants. Furthermore it is important that specific interests of tenants are addressed with modernization activities, although they might not be energy-related. This helps to get tenants support for renovation process.

Ambition versus market situation

Renovation of multi-storey building is planned to achieve high energy standards. In opposite to social housing sector commercial buildings are highly depending on market situation. If there is less interest on commercial areas with high energy standards (and thus also higher rents) it is very difficult to implement ambitious projects.

Optimized energy concept for whole community

Energy concept for new buildings can be planned and optimized since relevant figures and stakeholders are known. Integration of building stock causes several further questions such like:

- Figures about actual heat demand

- Figures about expected heat demand after renovations / modernizations

- Schedule of renovation process

Thus optimization has to consider several uncertainties respectively planning has to be modular. Further it has to be discussed who has to take the risk for additional costs.

\section{References}

[1] SIR - Salzburger Institut für Raumordnung und Wohnen: "StadtUMBAU LEHEN", Salzburg, 2010

[2] Steinbeis Transferzentrum Energie-, Gebäude- und Solartechnik: "Energiekonzept Mikronetz - Simulation, Wirtschaftlichkeit, Emissionen", Stuttgart, 2009

[3] Dr. Burkhard Schulze Darup, Schulze Darup \& Partner: "Rahmenplan für die Modernisierung der Strubergassensiedlung in Salzburg", Nürnberg, 2010

The project of "Stadtwerk Lehen" is funded by:

- European Union / Concerto

- BMVIT /Haus der Zukunft plus

- Land Salzburg / Wohnbauforschung 